\title{
Effect of Three Diluent Types and Equilibration'Times on the Quality and Fertility of Buffalo (Bubalus bubalis) Semen
}

\author{
Yendraliza*, Muhamad Rodiallah, Zumarni, Sadarman \\ Faculty of Agriculture and Animal Science, Universitas Islam Negeri Sultan Syarif Kasim Riau, JL. HR. Soebrantas \\ KM 15 Panam, Pekanbaru, Riau 28293 - Indonesia.
}

\begin{abstract}
The present research was conducted to determine the effects of three types of diluents and three equilibration times on the quality of buffalo semen. The experiment was arranged in a randomized block design having two factors, i.e., diluent types (tris egg-yolk, Andromed, and Triladyl) and equilibration times (3, 4, and 5 hours). In first stage of experiment, semen samples $(n=60)$ from two bulls were analyzed for motility $(\%)$, abnormality $(\%)$, membrane plasma integrity (\%), acrosome intact (\%), and recovery rate (\%). In second stage, semen fertility was tested on buffalo-cows $(n=90)$ by calculating the pregnancy rate (\%). Results showed that there was an interaction between diluent types and equilibration times on motility, membrane plasma integrity, acrosome intact, and recovery rate. The motility, membrane plasma integrity, acrosome intact, and recovery rate of buffalo sperm was higher $(p<0.05)$ with Andromed diluent than with tris egg-yolk and Triladyl diluents. Furthermore, the best equilibration time for buffalo semen was 5 hours rather than 3 and 4 hours. The pregnancy rate (86.67\%) was higher in buffaloes inseminated with Andromed diluent semen compared to tris egg-yolk (83.33\%) and Triladyl (56.67\%) diluents. In conclusion, Andromed diluent with 5 hours equilibration time have better effect on the characteristics of post-thaw semen and increase the pregnancy rate in swamp buffalo.
\end{abstract}

Keywords | Tris egg-yolk, Acrosome intact, Motility, Diluent, Pregnancy rate

Received | January 10, 2021; Accepted | January 19, 2021; Published | April 15, 2021

"Correspondence | Yendraliza, Faculty of Agriculture and Animal Science, Universitas Islam Negeri Sultan Syarif Kasim Riau, JL. HR. Soebrantas KM 15 Panam, Pekanbaru, Riau 28293 - Indonesia; Email: yendraliza@uin-suska.ac.id

Citation | Yendraliza, Rodiallah M, Zumarni, Sadarman (2021). Effect of three diluent types and equilibration times on the quality and fertility of buffalo (bubalus bubalis) semen. J. Anim. Health Prod. 9(2): 164-169.

DOI | http://dx.doi.org/10.17582/journal.jahp/2021/9.2.164.169

ISSN | 2308-2801

Copyright (C) 2021 Yendraliza et al. This is an open access article distributed under the Creative Commons Attribution License, which permits unrestricted use, distribution, and reproduction in any medium, provided the original work is properly cited.

\section{INTRODUCTION}

$\mathrm{T}$ he swamp buffalo (Bubalus bubalis) is one of the major part of livestock in Indonesia that had significant role in animal protein requirement of country. According to the Indonesian Statistics Department, the buffalo population in Indonesia has decreased by $42.5 \%$ during 2004 to 2018 (BPS, 2018). One of the efforts that can be made to increase the population of buffalo in Indonesia is by optimizing reproductive technology. Artificial insemination (AI) is a reproductive technology that is proven to be effective and can be widely applied in the field (Singh and Balharas, 2016). One of the factors for the success of the AI program is the quality of the frozen semen used.
The freezing technique, the type of diluent, as well as the type and concentration of cryoprotectants, have been known to determine the quality of frozen semen in livestock (Ariantie et al., 2013; Singh and Balharas, 2016). Contradictory reports were found regarding, i.e. (i) the ability of Andromed diluent and tris egg-yolk diluent to maintain the quality of bull sperm (Ansari et al., 2017); (ii) the ability of bioexcel diluents and tris citrate egg-yolk to maintain the quality of buffalo sperm (Shahverdi et al., 2014); (iii) the use of tris egg-yolk diluent, citrate egg-yolk, and fructose egg-yolk to maintain the quality of Friesian Holstein sperm (Arifiantini and Purwantara, 2010); (iv) the ability of Triladyl and egg yolk diluents to maintain the fertility of buffalo semen (Naz et al., 2018). All these 
aforementioned studies indicates the further research on semen diluents.

Buffalo sperm freezes quickly, and it is more sensitive to cold shock compared to cow sperm because buffalo spermatozoa contain phosphatidylcholine (60\%) and phosphatidylethanolamine (23\%) (Andrabi, 2009). At a critical temperature, any spermatozoa have different adaptability in integrating with the diluents used. Several studies have reported that a good equilibration time for buffalo sperm is 5 hours (Febriani et al., 2014), while other studies suggested two hours (Shahverdi et al., 2014). In response to the variety of results produced, there is a need to optimize the equilibration time and to determine the most suitable diluent type specifically for mud buffalo semen. Therefore, this study aimed to compare the effect of various diluents (tris egg-yolk, Andromed, and Triladyl) with different equilibration times $\left(3,4\right.$, and 5 hours) at $5^{\circ} \mathrm{C}$ on the quality of buffalo sperm. The study further investigated the resultant sperms for the pregnancy rate in buffaloes.

\section{MATERIALS AND METHODS}

\section{EXPERIMENTAL ANIMALS}

All the animal handling procedures in this experiment were carried out in compliance with the Animal Ethics and were approved by the Ethics Committee of the Faculty of Agriculture and Animal Science, UIN Suska Riau. The sample used in this study was the semen of a 5-years-old buffalo bulls $(n=2)$ that were maintained at the Tuah Sakato frozen semen station in Payakumbuh, Indonesia. Inseminations were then conducted on 90 buffalo-cows that had already given birth to Kampar, Riau, Indonesia. The temperature during the study was $22^{\circ} \mathrm{C}$ with $96 \%$ humidity. The semen was collected during January to March and insemination was carried out in April. The rectal palpation was conducted in July.

\section{DILUENT PREPARATION}

The tris egg-yolk diluent was obtained from the Tuah Sakato frozen semen station. Tris egg-yolk diluent (YET) was consists of $3.63 \mathrm{~g}$ tris (hydroxymethyl-aminomethane), $1.99 \mathrm{~g}$ citric acid, $0.50 \mathrm{~g}$ glucose, $74 \mathrm{~mL}$ distilled water, $20 \mathrm{~mL}$ egg yolk, $6.4 \mathrm{~mL}$ glycerol, $1000 \mathrm{IU} / \mathrm{mL}$ of penicillin (Pharmacia \& Upjohn, Belgium), and $1000 \mu \mathrm{g} /$ $\mathrm{mL}$ of streptomycin (Pharmacia \& Upjohn, Belgium). All chemicals were obtained from Sigma Aldrich (St. Louis, MO, USA). Both Andromed ${ }^{\circledR}$ (AND) and Trilady ${ }^{\circledR}$ (TRI) diluents were diluted with $80 \%$ distilled water (1:4) and homogenized.

\section{SEMEN PROCESSING}

Semen collection was carried out once a week for ten weeks per buffalo bull using an artificial vagina (IVM, France) at $42^{\circ} \mathrm{C}$. The only ejaculation collected had a sperm concentration greater than $800 \times 10^{6} \mathrm{sperm} / \mathrm{ml},>70 \%$ motility. After the collection, semen was observed microscopically (x400, Olympus B x 20, Tokyo, Japan) for sperm progressive motility, and sperm concentration was determined using a digital photometer (IVM, France). After the evaluation, the semen was divided into three aliquots and diluted with YET, AND or TRI at $37{ }^{\circ} \mathrm{C}$ according to freezing standards. After the dilution, the semen was infilled to straw $0.5 \mathrm{~mL}$ with a sperm concentration of $50 \times 10^{6}$ sperm $/ \mathrm{mL}$. For the sake of stability, the semen was maintained in a water bath for $10 \mathrm{~min}$ at $35^{\circ} \mathrm{C}$ and then cooled from $35^{\circ} \mathrm{C}$ to $25^{\circ} \mathrm{C}$ in one hour at room temperature. The straw was cooled from $25^{\circ} \mathrm{C}$ to $4{ }^{\circ} \mathrm{C}$ in a cold cabinet and equilibrated for 3, 4 and 5 hours. The pre-freezing process was carried out by placing the straw on a liquid nitrogen surface as high as $3 \mathrm{~cm}$ using a Styrofoam box for $10 \mathrm{~min}-$ utes at a temperature of $-100^{\circ} \mathrm{C}$. The straw was dipped and store in liquid nitrogen at $-196{ }^{\circ} \mathrm{C}$ for 24 hours.

\section{EVALUATION OF SEMEN QUALITY CHARACTERISTICS}

The frozen semen thawing was carried out in a water bath for 30 second at $37^{\circ} \mathrm{C}$ to evaluate sperm motility, abnormality, viability, plasma membrane integrity, and acrosome integrity (Sarı̈̈zkan et al., 2014). Motility was measured eight times under a light microscope with a 400x magnification lens. The number of moving spermatozoa was determined between 0 to $100 \%$ with a $5 \%$ scale. About 200 spermatozoa were observed by means of eosin-nigrosine staining under a light microscope with a 400x magnification lens. Live spermatozoa were marked with a clear head, while a red one marked those that died. Abnormality of spermatozoa was observed under a microscope with a magnification lens of 450x. The sample was prepared by mixing one drop of semen with one drop of eosin. The 200 spermatozoa cells were counted to determine the normal and abnormal ratio (Garner and $\mathrm{Hafez}, 2016)$. Acrosome intact (\%) indicated the acrosome hood of the spermatozoa and was evaluated through a phase-contrast microscope with a magnification lens of $100 x$ by killing and fixation of spermatozoa mixed with $\mathrm{NaCl}$ plus $1 \%$ formalin. The evaluation was carried out using a 0 to $100 \%$ rating system for 200 spermatozoa. Plasma membrane integrity (\%) was characterized by coiled spermatozoa tails after being put into $0.032 \mathrm{M} \mathrm{NaCl}$ hypoosmotic medium $(0.17 \mathrm{~g} \mathrm{NaCl}$ in $100 \mathrm{~mL}$ distilled water). Afterward, incubation was carried out at $37^{\circ} \mathrm{C}$ for one hour. The evaluation was performed under a light microscope with 40x magnification lens. The results were rated in the scoring system of $0 \%$ to $100 \%$, while the recovery rate was calculated by subtracting fresh sperm motility with sperm motility after freezing.

\section{Artificial InSEMination}

In second stage, the semen was used for AI on 90 buffalo- 
Table 1: The characteristics of fresh buffalo semen.

\begin{tabular}{ll} 
Characteristics & Average with standard deviation \\
\hline Macroscopic characteristics & \\
\hline Volume (ml) & $1.23 \pm 0.30$ \\
$\mathrm{pH}$ & $7.0 \pm 0.0$ \\
Color & Cream \\
\hline Consistency & Thick \\
\hline Microscopic characteristics & \\
\hline Concentration (million/ml/ejaculation) & $1.23 \pm 7.25$ \\
\hline Mass activity (0-5 scale) & $3.0 \pm 7.8$ \\
\hline Individual activity (0-5 scale) & $2.0 \pm 0.0$ \\
\hline Motility (\%) & $76.3 \pm 5.50$ \\
\hline Viability (\%) & $73.21 \pm 0.65$ \\
\hline Abnormality (\%) & $8.0 \pm 1.0$ \\
\hline Plasma membrane integrity (\%) & $68.3 \pm 5.77$ \\
\hline
\end{tabular}

Table 2: Effect of different diluents and equilibration time on characteristics of buffalo semen samples after thawing at $37^{\circ} \mathrm{C}$.

\begin{tabular}{|c|c|c|c|c|}
\hline \multirow[t]{2}{*}{ Variables (\%) } & \multirow[t]{2}{*}{ Diluents } & \multicolumn{3}{|c|}{ Equilibration times (hours) } \\
\hline & & 3 & 4 & 5 \\
\hline \multirow[t]{3}{*}{ Motility } & Tris-egg yolk & $42.33 \pm 2.53^{\mathrm{bB}}$ & $45.00 \pm 7.26^{\mathrm{bB}}$ & $56.17 \pm 8.41^{\mathrm{aA}}$ \\
\hline & Andromed & $50.00 \pm 0.39^{\mathrm{aB}}$ & $59.76 \pm 0.46^{\mathrm{aA}}$ & $65.55 \pm 0.31^{\mathrm{aA}}$ \\
\hline & Triladyl & $35.67 \pm 8.7^{\mathrm{cB}}$ & $37.33 \pm 3.4^{\mathrm{cB}}$ & $32.03 \pm 7.9^{\mathrm{bB}}$ \\
\hline \multirow[t]{3}{*}{ Abnormality } & Tris-egg yolk & $12.76 \pm 4.0$ & $12.50 \pm 4.2$ & $11.38 \pm 2.5$ \\
\hline & Andromed & $11.00 \pm 1.3$ & $11.01 \pm 2.4$ & $10.11 \pm 1.2$ \\
\hline & Triladyl & $15.45 \pm 5.4$ & $16.67 \pm 5.5$ & $17.65 \pm 3.2$ \\
\hline \multirow[t]{3}{*}{ Plasma membrane integrity } & Tris-egg yolk & $49.27 \pm 15.5^{\mathrm{bB}}$ & $45.50 \pm 13.5^{\mathrm{bB}}$ & $65.00 \pm 8.9^{\mathrm{aA}}$ \\
\hline & Andromed & $52.33 \pm 2.39^{\mathrm{bB}}$ & $53.67 \pm 3.46^{\mathrm{aB}}$ & $65.17 \pm 3.40^{\mathrm{aA}}$ \\
\hline & Triladyl & $40.56 \pm 7.06^{\mathrm{bA}}$ & $42.00 \pm 8.90^{\mathrm{bA}}$ & $47.67 \pm 3.65^{\mathrm{bA}}$ \\
\hline \multirow[t]{3}{*}{ Acrosome integrity } & Tris-egg yolk & $65.17 \pm 15.29^{\mathrm{aB}}$ & $60.83 \pm 11.27^{\mathrm{aB}}$ & $75.00 \pm 9.01^{\mathrm{aA}}$ \\
\hline & Andromed & $62.33 \pm 0.39^{\mathrm{aB}}$ & $63.67 \pm 0.46^{\mathrm{aB}}$ & $77.17 \pm 0.31^{\mathrm{aA}}$ \\
\hline & Triladyl & $57.67 \pm 5.06^{\mathrm{aA}}$ & $57.00 \pm 3.91^{\mathrm{aA}}$ & $53.67 \pm 7.65^{\mathrm{bA}}$ \\
\hline
\end{tabular}

Note: means with different uppercase superscripts $(A, B)$ in a row showing significant difference (at $p<0.05$ ) between the equilibration times, while means with different lowercase superscripts $(a, b, c)$ in a column showing significant difference $(a t p<0.05)$ between the diluents.

Table 3: The rate of recovery and pregnancy rate of buffalo-cows in response to different diluent types with an equilibration time of 5 hours.

$\begin{array}{lll}\text { Diluent types } & \text { Recovery rate (\%)* } & \text { Pregnancy rate (\%) } \\ \text { Tris-egg yolk } & 73.61^{\mathrm{b}} & 83.33(25 / 30) \\ \text { Andromed } & 85.91^{\mathrm{c}} & 86.67(26 / 30) \\ \text { Triladyl } & 41.97^{\mathrm{a}} & 56.67(17 / 30) \\ \text { * means with different alphabet superscripts in the same column are significantly different at } \mathrm{p}<0.05 . \text {. Recovery rate was calculated by } \\ \text { subtracting sperm motility after freezing from fresh sperm motility. }\end{array}$

cows that had already given birth with a bodyweight of $400-450 \mathrm{~kg}$. All of the selected buffalo-cows were synchronized using $3 \mathrm{~mL} / \mathrm{animal}$ (tail) gonadotropin-releasing hormone $\left(\mathrm{GnRH}\right.$; Fertagy $\left.{ }^{\circledR}\right)$ on the first day and 2.5 $\mathrm{ml}$ prostaglandin $\mathrm{F} 2$ alpha (PGF2 $\alpha$ ) in the form of Dinoprost tromethamine $(10 \mathrm{~mL}$; a synthetic analogue of the naturally occurring PGF2 $\alpha$ ) on the 7 th day after GnRH injection. The buffalo showed estrus after the injection of 
PGF2 $\alpha$ were inseminated with frozen semen from the first stage of the research. A total of 90 inseminations (30 inseminations/extenders) were tested on buffalo-cows in Kampar, Riau, Indonesia. Pregnancy was detected 60 days after artificial insemination by rectal palpation. The pregnancy rate was calculated by dividing the number of pregnant buffaloes by the number of buffaloes inseminated.

\section{DATA ANALYSIS}

Data were presented as mean \pm standard deviation. Data were statistically analyzed using Minitab 17 for Windows with a Randomized Block Design of two factors with three equilibration times, three types of diluents, and ten replications, except for the analysis of pregnancy rates with descriptions. The Duncan Multiple Range test was performed to compare the differences between groups. The difference in treatments was considered significant at $\mathrm{P}<0.05$ (Steel et al., 1991).

\section{RESULTS}

The quality of fresh buffalo semen was presented in Table 1.The average semen volume per ejaculation was $1.23 \pm 0.30$ $\mathrm{ml}$ with $7 \mathrm{pH}$. The mean motility, plasma membrane integrity, and acrosome integrity of buffalo semen were significantly affected $(\mathrm{P}<0.01)$ except for the mean abnormalities by different types of diluent and equilibration time after the thawing at $37^{\circ} \mathrm{C}$ (Table 2). The use of Andromed diluents produced the highest motility, abnormality, membrane plasma integrity, and acrosome intact compared to egg yolk-tris and Triladyl diluent. The equilibration times of about 5 hours and 4 hours showed higher motility than that of 3 hours. Furthermore, the recovery rate and pregnancy rate from the use of Andromed and tris egg-yolk were higher than those produced from Triladyl diluent (Table 3).

\section{DISCUSSION}

The quality of fresh buffalo semen was good and feasible to be diluted (National Standardization Agency of Indonesia 2008). The average volume of semen in the study was $1.23 \pm 0.30 \mathrm{ml}$, which was similar to Das et al. (2017) who reported that the volume of fresh semen in swamp buffalo of Assam ranged between $1.08 \pm 0.06$ to $1.78 \pm 0.21 \mathrm{ml}$. However, Koonjaenak et al. (2007) reported higher volumes of 3.2 to $3.8 \mathrm{~mL}$ in swamp buffalo in Thailand. The mass activity in this study $(3 \pm 7.8)$ was lower than that of swamp buffaloes in India $(3.51 \pm 0.12$ to $3.78 \pm 0.06)$ (Das et al., 2017). The sperm motility found in this study $(76.3 \pm 5.50 \%)$ was similar to the one found in Thai swamp buffaloes (72.8 to 75.2\%) (Koonjaenak et al., 2007), but was in contrast to that in Indian swamp buffaloes $78.94 \pm 0.49 \%$ (Das et al., 2017). The viability of sperms of swamp buf- faloes in this study $(73.21 \pm 0.65 \%)$ was lower than that of swamp buffaloes in India $89.36 \pm 0.85$ to $90.21 \pm 0.8$ (Das et al., 2017). However, the sperm concentration of swamp buffaloes found in this study $(1.233 \pm 7.25$ million/ $\mathrm{mL}$ ) was higher than that of swamp buffaloes in India (1.057.08 \pm 29.07 million/ml) (Das et al., 2017) and in Thailand (1.1 to 1.2 billion/ml) (Koonjaenak et al., 2007). The differences in motility, viability, and concentration between swamp buffaloes are attributable to difference in environment, feed, age, shelter, and season (Garner and Hafez, 2016).

The current study found best motility and viability of buffalo sperm in Andromed diluent with an equilibration time of 5 hours (Table 2). It was caused by different chemical composition among the three tested diluents (Manjunath, 2012). The lecithin content in Andromed diluent can protect the plasma membrane and safeguard the cholesterol and phospholipids of the spermatozoa membrane. High concentration of lecithin can help absorb protein in the seminal plasma and protect sperm from cold (Barbonetti et al., 2010). The composition in the Andromed diluent stimulates the production of ATP so that sperm motility and vitality can be maintained (Gordon, 2017). The motility of buffalo semen in the present study differed from the motility of spotted buffalo (70.11\% vs $41.67 \%$ ) (Yulnawati et al., 2010), Nili Ravi in optixell diluent with $4 \mathrm{~h}$ equilibration (35.11 $\pm 0.8 \%)$ (Naz et al., 2018), Nili-Ravi buffalo in Pakistan in Andromed diluent with $4 \mathrm{~h}$ equilibration (75 $\pm 2.0 \%)$ (Ansari et al., 2017), and the motility of buffalo study in Iran in tris egg-yolk and bioexell diluent with $2 \mathrm{~h}$ equilibration (Shahverdi et al., 2014). The difference in the mentioned results seemed due to the variation in livestock type, age, and storage conditions of semen (Jainudeen and Hafez, 2016).

In this study, no change was observed in the abnormality of buffalo sperm between various types of diluents and equilibration times which is in agreement to previous report (Ariantie et al., 2013). In agreement to our study Febriani et al. (2014) also reported that compared to 5 hours, 3 and 4 hours equilibration time are deleterious for sperms viability as these equilibration durations leading to the death of spermatozoa after thawing.

The plasma membrane integrity was positively correlated with viability and acrosomal integrity. The plasma membrane plays an important role in regulating the whole process inside the cell (Gordon, 2017). The good plasma membrane integrity shows that the sperm can adapt to the diluent at an equilibration so that the transport of the substrate and electrolytes out of the membrane runs well and cell metabolism runs normally (Manjunath, 2012). Membrane integrity is needed to support sperm motility in the process of fertilization, capacitation, and adsorption 
(Rastegarnia et al., 2013). We found higher supravital plasma membrane integrity, spermatozoa viability, and intact acrosome by Andromed diluent with $5 \mathrm{~h}$ equilibration at post-thawing. The protective agent in the Andromed is believed to be the low-density lipoprotein (LDL) fraction (Singh et al., 2018). The plasma membrane integrity in this study also differed from the plasma membrane integrity found in similar study on Aceh buffalo semen (Eriani et al., 2017), Nili-Ravi buffalo in tris egg-yolk diluent with 4 h equilibration (80\%) (Qadeer et al., 2015), and Indonesian swamp buffalo in skim egg-yolk diluent with 4 hours equilibration (51.38 to $62.41 \%$ ), probably due to the different diluents used (Herbowo et al., 2019). The variety of semen quality and livestock age also made a difference in the plasma membrane integrity (Garner and Hafez, 2016). In general, the rate of acrosome intact in the present experiment was still above the standard for buffalo sperm (National Standardization Agency of Indonesia, 2008). We found a higher sperm percentage of acrosome intact in Andromed diluent with 5 hours equilibration than in the tris egg-yolk and Triladyl. The acrosome intact of buffalo sperm in the present study was different from that of Pakistani buffalo (Shah et al., 2016) and Nili- Ravi buffalo in Optiexell with 4 hours equilibration (Naz et al., 2018). The difference of acrosome intact was probably caused by the difference in animal species, diluent types, and preservation techniques (Manjunath, 2012). In this study, the best equilibration time was obtained at 5 hours (67.72\%), similar to Febriani et al. (2014). However, it was different from Shahverdi et al. (2014) and Leite et al. (2010) which found the best equilibration time at about 2 hours and Eriani et al. (2017); Shah et al. (2016) and Kumar et al. (2015) at 4 hours for swamp buffalo. When stored under aerobic conditions, the amino acids in egg yolks produce hydrogen peroxide, which is toxic to sperm (Hezavehei et al., 2018). This shows that the equilibration time of 5 hours help buffalo spermatozoa in adaptation and its' interaction with the diluent so that the spermatozoa membrane's integrity and the balance of intracellular and extracellular water well protected by the diluent (Benson et al., 2012).

The results of the recovery rate and the pregnancy rate of buffalo-cows with Andromed diluent with 5 hours equilibration were higher than with tris egg-yolk and Triladyl with 3 and 4 hours equilibration, which was probably caused by the differences in motility, viability, membrane plasma integrity, and acromosome intact of the semen used (Das, 1985). The pregnancy rate in this study was higher than reported in previous studies in buffaloes ( $\mathrm{Naz}$ et al., 2018; Ansari et al., 2017; Kumar et al., 2015). Garner and Hafez (2016) reported that the motility affects the ability of sperm to fertilize an egg. Besides, the buffaloes used also had different body weights, resulting in different individual responses to the success of artificial insemination (Gordon,
2017).

\section{CONCLUSION}

The best buffalo semen characteristics were exhibited by the Andromed diluent with an equilibration time of 5 hours compared to tris egg yolk and Triladyl diluent with 4 hours and 3 hours equilibration time. Meanwhile, the highest pregnancy rate $(86.67 \%)$ was produced with the use of Andromed diluent.

\section{ACKNOWLEDGMENTS}

The authors would like thank to the director and all staff of Tuah Sakato buffalo breeding center in Payakumbuh, West Sumatera Province that has facilitates and provided assistance during the experiment. In addition, the authors thank to Universitas Islam Negeri Sultan Syarif Kasim Riau for the financial support.

\section{CONFLIC'T OF INTEREST}

We declare there is no conflict of interest with personal, financial, or other relationships with any person or organization related to the materials discussed in the manuscript.

\section{AUTHOR CONTRIBUTION}

Yendraliza and Zumarni designed, conducted research activities and revised manuscript. Muhamad Rodiallah and Sadarman analyzed data and wrote manuscript. The all authors contributed to conducting research and writing this manuscript.

\section{REFERENCES}

-Andrabi SMH (2009). Factors affecting the quality of cryopreserved buffalo ( bubalus bubalis ) bull spermatozoa. Reprod. Domest. Anim. 44(3): 552-569. https://doi. org/10.1111/j.1439-0531.2008.01240.x

-Ansari MS, Rakha B and Akhter S (2017). Cryopreservation of Nili-Ravi buffalo (Bubalus bubalis) semen in Andromed ${ }^{{ }^{\circledR}}$ extender; in vitro and in vivo evaluation. Reprod. Domest. Anim. 52(6): 992-997. https://doi.org/10.1111/rda.13008

-Ariantie O, Yusuf T, Sajuthi D, Arifiantini R (2013). Pengaruh krioprotektan gliserol dan dimethilformamida dalam pembekuan semen kambing peranakan etawah menggunakan pengencer tris modifikasi. J. Ilmu Ternak dan Vet. 18(4): 239-250.

-Arifiantini R, Purwantara B (2010). Motility and viability of friesian holstein spermatozoa in three different extender stored at $5^{\circ} \mathrm{C}$. J. Indonesian Trop, Anim. Agric. 35(4): 222226. https://doi.org/10.14710/jitaa.35.4.222-226

-BPS. (2018). Buffaloes Indonesia. Statistic. Jakarta.

-Benson JD, Woods EJ, Walters EM, Critser JK (2012). The cryobiology of spermatozoa. Theriogenology. 78(8): 1682- 
1699. https://doi.org/10.1016/j.theriogenology.2012.06.007

- Barbonetti A, Vassallo MRC, Fortunato D, Francavilla S, Maccarrone M, Francavilla F. (2010). Energetic metabolism and human sperm motility: Impact of CB1 receptor activation. Endocrinology. 151(12): 5882-5892. https://doi. org/10.1210/en.2010-0484

- Das GC, Das PK, Deori S, Mazumdar H, Bhattacharyya BN, Phookan A (2017). Seasonal variation in the characteristics of the swamp buffalo semen of northeast India. Buffalo Bulletin. 36(1): 215-219.

-Das RP (1985). Assessment of spermatozoal function. J. Biosci. 7(2): 245-255. https://doi.org/10.1007/BF02703594

-Eriani K, Sari N, Ihdina M, Rosnizar (2017). The effect of equilibration time on semen freezing of local swamp buffalo (Bubalus bubalis) with combination diluent of lactose and glycerol. Nusantara Biosci. 9(1): 77-82. https://doi. org/10.13057/nusbiosci/n090113

-Eriani K, Sari N, Rosnizar, Dasrul, Suhartono, Rizal M (2017). Cryopreservation of Aceh swamp buffalo (Bubalus bubalis) semen with combination of glycerol and lactose. J. Biol. Biol. Education.9(3): 409.https://doi.org/10.15294/biosaintifika. v9i3.11426

- Febriani GD, Hamdan, Melia J (2014). The influence of time equilibration to the quality of the swamp buffalo (Bubalus bubalis) semen. J. Medika Vet. 8(1): 1-4.

- Garner DL, Hafez ESE (2016). Spermatozoa and Seminal Plasma. In Reproduction in Farm Animals, Baltimore: Lippincott Williams \& Wilkins, 96-109 https://doi. org/10.1002/9781119265306.ch7

- Gordon I (2017). Reproductive technologies in farm animals. Cabi. https://doi.org/10.1079/9781780646022.0000

- Herbowo MT, Arifiantini RI, Karja NWK, Sianturi RG (2019). Trop. Anim. Sci. J. 42(1): 13-18. https://doi.org/10.5398/ tasj.2019.42.1.13

- Hezavehei M, Sharafi M, Kouchesfahani H, Mohseni R, Henkel, Agarwal A, Esmaeili V, Shahverdi A (2018). Sperm cryopreservation: A review on current molecular cryobiology and advanced approaches. Reprod. BioMed. 37(3): 327-339. https://doi.org/10.1016/j.rbmo.2018.05.012

- Holt W (2000). Basic aspects of frozen storage of semen. Anim. Reprod. Sci. 62(1-3): 3-22. https://doi.org/10.1016/S03784320(00)00152-4

- Leite TG, do Vale Filho VR, de Arruda RP, de Andrade AF, Emerick LL, Zaffalon FG (2010). Effects of extender and equilibration time on post-thaw motility and membrane integrity of cryopreserved Gyr bull semen evaluated by CASA and flow cytometry. Anim. Reprod. Sci. 120(14):31-38. https://doi.org/10.1016/j.anireprosci.2010.04.005

-Jainudeen MR, Hafez ESE (2016). Cattle and Buffalo. In Reproduction in Farm Animals, Baltimore: Lippincott Williams \& Wilkins. 157-171. https://doi. org/10.1002/9781119265306.ch11

- Koonjaenak S, Chanatinart V, Aiumlamai S, Pinyopumimintr T, Rodriguez-Martinez H (2007). Seasonal variation in semen quality of swamp buffalo bulls (Bubalus bubalis) in Thailand. Asian J. Androl. 9(1): 92-101. https://doi.org/10.1111/ j.1745-7262.2007.00230.x

- Kumar P, Saini M, Kumar D, Balhara AK, Yadav SP, Singh P and Yadav P S (2015). Liposome-based semen extender is suitable alternative to egg yolk-based extender for cryopreservation of buffalo (Bubalus bubalis) semen. Animal Reprod. Sci. 159: 38-45. https://doi.org/10.1016/j. anireprosci.2015.05.010

- Manjunath P (2012). New insights into the understanding of the mechanism of sperm protection by extender components. Anim. Reprod. Sci. 9(4): 809-815.

- Minitube (2001). Certificate Andromed. Retrieved February 142019 from https://www.minitube.com/pdf/ index/13503-0200_Leaflet-AndroMed_en_171002.pdf

- National Standardization Agency of Indonesia (2008). SNI 4869.2-2008 Semen Beku Kerbau. Retrieved February 10, 2019, from https://id.scribd.com/document/345026647/ SNI-4869-2-2008-Semen-Beku-Kerbau

- Naz S, Umair M and Iqbal S (2018). Comparison of tris egg yolk-based, Triladyl ${ }^{\circledR}{ }^{\oplus}$ and optixell ${ }^{\circledast}$ extender on post-thaw quality, kinematics and in vivo fertility of nili ravi buffalo (Bubalus bubalis) bull spermatozoa. Andrologia. 50(8) :13063. https://doi.org/10.1111/and.13063

- Qadeer S, Khan MA, Ansari MS, Rakha BA, Ejaz R, Iqbal R, Younis M, Ullah N, de Vries AL, Akhter S (2015). Efficiency of antifreeze glycoproteins for cryopreservation of Nili-Ravi (Bubalus bubalis) buffalo bull sperm. Anim. Reprod. Sci. 157: 56-62. https://doi.org/10.1016/j.anireprosci.2015.03.015

- Rastegarnia A, Shahverdi A, Rezaei Topraggaleh T, Ebrahimi B, Shafipour V (2013). Effect of different thawing rates on post-thaw viability, kinematic parameters and chromatin structure of buffalo (bubalus bubalis) spermatozoa. Cell J. 14(4):306-313.

-Sarı̈zkan S, Özdamar S, Türk G, Cantürk F, Yay A (2014). In vitro effects of $\mathrm{L}$-carnitine and glutamine on motility, acrosomal abnormality, and plasma membrane integrity of rabbit sperm during liquid-storage. Cryobiology. 68(3): 349-353. https://doi.org/10.1016/j.cryobiol.2014.04.006

-Shah SA, Andrabi S M and Qureshi I Z. (2016). Effect of equilibration times, freezing, and thawing rates on postthaw quality of buffalo (Bubalus bubalis) bull spermatozoa. Andrology. 4(5): 972-976. https://doi.org/10.1111/ andr.12214

- Shahverdi A, Rastegarnia A, Rezaei T (2014). Effect of extender and equilibration time on post thaw motility and chromatin structure of buffalo bull (Bubalus bubalis) spermatozoa. Cell J. 16(3): 279-288.

- Singh M, Rajoriya JS, Kumar A, Ghosh SK, Prasad JK (2018). Cryopresevation of Buffalo (Bubalus bubalis) Semen; Current Status and future Prospective. Buffalo Buletin. 37(2): 110-128.

- Singh I, Balhara AK (2016). New approaches in buffalo artificial insemination programs with special reference to India. Theriogenology. 86(1): 194-199. https://doi.org/10.1016/j. theriogenology.2016.04.031

- Steel RGD, George D, Torrie JH, Sumantri B (1991). Prinsip dan prosedur statistika: suatu pendekatan biometrik. Gramedia Pustaka Utama, Jakarta.

-Yulnawati M, Gunawan H, Maheswari, Rizal M, Herdis, Boediono A (2010). Quality of Epididymal and Ejaculated Sperms of Spotted Buffalo in Dextrose Supplemented Extender. HAYATI J. Biosci. 17(1): 27-30. https://doi. org/10.4308/hjb.17.1.27 